\title{
CREATING NORMALCY: FOSTER CARE FOR CHILDREN AND YOUTH WITH DISABILITIES AND MEDICAL FRAGILITY IN GERMANY
}

\section{Friedegard Föltz}

\begin{abstract}
In the area of foster care concerning children and youth with special needs due to disability or medical fragility, there is a paucity of knowledge and research. In Germany, these groups in foster care who have high special needs are an invisible and neglected population at risk. These children and youth are mostly cared for in residential homes; however, some are living in foster families and benefit from a familial setting. The purpose of the study was to understand how foster parents manage their lives with a child or youth who has special needs, and how they meet the challenges that arise. The qualitative research design used the method of narrative inquiry through in-depth interviews, which were conducted in the German state of Saxony-Anhalt with 19 foster parents from 15 families. Within the framework of grounded theory, the author developed a theoretical structure of the strategies foster parents use for coping. Results showed that foster parents dealt with this new and often unpredictable situation by applying one of three patterns of strategies - action-, resource-, or reflection-oriented — based on their personal experiences and worldview. Understanding these behavioral patterns gives administrative and supportive entities like child welfare systems and agencies a unique and tailored approach to recruit, retain, train, and counsel foster families adequately, and to strengthen their well-being and their ability to perform well for themselves and their children and youth.
\end{abstract}

Keywords: child welfare, fostercare, foster parents, foster children, disability, medical fragility, coping strategies

Friedegard Föltz $\mathrm{PhD}$ is a lecturer and the head of the Bachelor of Arts Social Work program in the Department of Social Sciences, Theologische Hochschule Friedensau, An der Ihle 19, 39291 Friedensau, Germany. Email: friedegard.foeltz@thh-friedensau.de 
International Journal of Child, Youth and Family Studies (2020) 11(4): 132-151

The study presented in this article concerns the topic of foster care in the state of SaxonyAnhalt, Germany, especially with regard to children and youth with disabilities or those who are medically fragile. The situation and reality of life in foster families is neither well known nor well studied (Braches-Chyrek et al., 2010, p. 6; Hanselmann \& Weber, 1986, p. 107). Even less studied is the situation of foster families with children and youth who are affected by disability. In Germany, children and youth with high special needs who are in foster care are an invisible and neglected population at risk.

The subject of this study is permanent care for children and youth who are not only affected by issues like neglect, deprivation, maltreatment, abuse, and trauma that are typically dealt with in foster care, but in addition have high special needs for support and assistance because of a disability or medical fragility. Foster parents find themselves under pressure as they deal with psychiatric problems and stressful behaviors like aggressive, obsessive, or self-injuring behavior; movement disorders (e.g., stereotypies); self-endangerment and endangerment of others; extreme restlessness; and feeding and eating disorders (Föltz, 2017, p. 297). In such a situation, the needs of the children and their foster parents intensify. The children and youth need differentiated medical, therapeutical, and psychological help, while the foster parents are in need of information and instruction in order to meet the needs of the child adequately and knowledgeably (Gadow et al., 2013, p. 165).

My research (Föltz, 2017) shows that three patterns can be identified in the ways each foster parent develops his or her individual strategies to meet those needs and to create (or recreate) a subjective normalcy in life. These patterns constitute themselves in accordance with the foster parent's individual view of themselves acquired through their personal experiences and worldview. According to those, schemes of life and actions are carried out (Föltz, 2017, p. 5).

Foster care is provided for children and youth who temporarily or permanently cannot live in their family of origin because of a problematic situation in the family such as neglect, maltreatment, domestic violence, illness, disability, alcohol abuse, or delinquency. Through an institutional intervention, those children are placed in another family, usually one unknown to them (Sozialgesetzbuch [social law book; SGB] VIII, §§27-35). Taking a child out of the child's home is often regarded as providing protection and opportunity, but at the same time it is an intrusion that implies sanction and taking control (Trede, 2002, p. 11).

In Germany, out-of-home care is provided as either residential care (SGB VIII, §34); familial care, which can be foster care with its various characteristics (day care, week care, short term care, care on call, permanent care, specialized care such as sociopedagogical or therapeutic care); or kinship care (SGB VIII, §33; Föltz, 2017, pp.17-23). The term "resource families", which is used in the United States, is an appropriate description for much of the content dealt with in this study. In comparison to the rest of Europe, Germany still relies more on residential care than on any form of familial care (Trede, 2001, p. 210). 
The overall objective of this study was to understand how foster parents handle their lives with a child or youth who has high special needs. Out of my personal experiences as a foster parent sharing my life with three children, siblings with mental disabilities due to fetal alcohol spectrum disorder, I aimed to shine a light upon this area of foster care that mostly goes unnoticed and unappreciated in daily life and research.

A brief literature survey reveals that research about the situation of families with biological children with disabilities is manifold (Engelbert, 1999, pp. 11, 18). In a significant number of studies, parents of a child with a disability report more stress and depression than parents of a child without a disability (Retzlaff, 2010, p. 59). However, little research has been done in the field of foster care, much less than in comparable fields like adoption and residential care.

With regard to foster families with children and youth with special needs, there have only been a few studies done over the last four decades. In 1982, Masur and colleagues examined the question of whether the subjective impression that children with disabilities are neglected in the process of placements is true in practice. Kwapil (1987) looked at the motivation of foster parents with children with disabilities as well as at pedagogical aspects of this specific form of foster care. In 1999, Heinen and Höning had a catalogue of questions for 22 foster parents with children with a mental disability. Also in 1999, Koppe et al. (2000) presented their results from a 1997 study with 694 foster parents with children in special care, which had a response rate of 29\%. They emphasized that there is no uniform type of foster family and that this was good news because different children need different families. Foster families with children with physical and mental disabilities have different problems and needs than those with children with emotional disabilities. Schäfer (2011) studied the situation of 87 foster families with children who had limited life expectancy because of a chronic illness or disability. He was investigating stresses, resources, and essential support measures in the context of both private and societal conditions. Sarimski (2014) presented a study with 71 foster and adoptive parents with children affected by fetal alcohol spectrum disorder; compared to another group of foster parents with children with disabilities and chronic diseases, they showed significantly higher stress levels.

On the whole there is only sparse research in the specialized field of foster care for children with high special needs, especially research with a qualitative approach, which describes the subjective experiences of foster parents. International developments in the practice of foster care have been insufficiently adopted in Germany, and, in general, accepted quality standards like evidence-based measures and procedures are lacking (Kindler et al., 2011, pp. 18-19). This study's objective was to contribute to the research groundwork in foster care in Germany in order to shed some light on the needs of foster parents administering care for their children and youth who have high special needs. Since the study is regionally specialized with a focus on the state of SaxonyAnhalt, it would be desirable to have even more regional studies for a comprehensive view on the situation in Germany. 
International Journal of Child, Youth and Family Studies (2020) 11(4): 132-151

\section{Study Background}

At the end of the year 2007, 49,673 children and youth lived in permanent foster care in Germany and 52,793 in residential homes (Statistisches Bundesamt, 2009, S. 69). In these statistics, a distinction is made between permanent foster care and special care, but special care is not further differentiated into sociopedagogical care and therapeutic care; therefore, the number of children with disabilities in permanent foster care cannot be ascertained (Statistisches Bundesamt, 2018, Tb. 1.2, 2a). Six years later, in 2013, the numbers in Germany increased to 67,812 children and youth in permanent foster care and 69,203 in residential care (Statistisches Bundesamt, 2013, p. 17). In 2018, 75,318 children and youth lived in permanent foster care, and 90,997 in residential group homes (Statistisches Bundesamt, 2018, Tb. 1.2, 2a). The trend in society to even more outof-home care over the years is obvious (Gadow et al., 2013, pp. 168, 181).

According to the office of statistics of the state of Saxony-Anhalt (Landesverwaltungsamt Sachsen-Anhalt, 2003), 4,598 children and youth were living in out-of-home care in 2003: 2,034 of them were cared for in foster homes, and 117 (5.75\%) of these were children with disabilities. There were 2,564 children and youth living in residential settings (Landesverwaltungsamt Sachsen-Anhalt, 2003).

Eleven years later, in 2014, 5,666 children and youth were living in out-of-home care, with 2,294 in foster families; among the latter were 138 (6.02\%) with a disability (Landesverwaltungsamt Sachsen-Anhalt, 2014). There were 3,372 children and youth in residential group homes, among them 265 (7.86\%) in specialized homes for children with disabilities (Landesverwaltungsamt Sachsen-Anhalt, 2014). In the following years, the number of children and youth with disabilities was not determined.

In Germany, according to the SGB IX, care for children with disabilities who cannot live in their family of origin is provided above all in special group homes, in therapeutic homes, or in specialized institutions, such as those for children who are blind or physically impaired (Roos, 1996, p. 197). There is little willingness in the child welfare systems to undertake efforts to place children and youth with disabilities and medical fragility in family-like settings (Masur et al., 1982, p. 120). Yet it is highly preferable for these children to have experiences and fostering in a familial and manageable framework with primary attachment figures (Schönecker, 2011, p. 807; Thiersch, 1992, p. 107) for economic, pedagogical, and therapeutic reasons, and reasons of general human dignity (Roos, 1996, p. 200).

In practice, however, this kind of family-like care is rarely or never granted. Not only is the process of the placement itself challenging, the authorities disagree over responsibilities: children and youth with a physical or mental disability are assigned to the realm of social welfare (SGB IX, ch. $13, \S 80$, while children and youth with an emotional disability are assigned to child and youth welfare (SGB VIII, §35a). When there is both a disability and a deficit in parenting skills, it is often not easy to decide whether the disability or the lack of parenting skills accounts for the need 
for help. As a result, it is difficult to determine which authority is responsible, even though the legislation is explicit about how both types of case should be handled.

When there are deficits in parenting skills serious enough to cause an institutional intervention, the child and youth welfare system will generally be the responsible authority. For a long time, family care was seen as exclusively a benefit of the child welfare system, and was not part of the social welfare system to which children and youth with disabilites were assigned. However, in 2009 , foster care was made possible in the social welfare system, though with temporal limitations. As of 2020, foster care is explicitly part of the social welfare system with no temporal limitation.

Nevertheless, it can be anticipated that as long as out-of-home care for children and youth with disabilities remains the responsibility of the social welfare system, those children will be at a disadvantage compared to children in the child and youth welfare system. The child and youth welfare system, where children have access to multiprofessional help, should have the authority and responsibility for all children and youth (Schönecker, 2011, pp. 807-811). As early as 1980 the Fifth Youth report of the Federal Republic (Fünfter Jugendbericht der Bundesregierung, 1980) criticized the fragmentation of help and the corresponding disadvantages for the children concerned. There were even suggestions for remedies. Unfortunately, in the last 40 years nothing has changed in this area. One group of foster families has special needs children and youths who are in the care of the better-equipped child and youth welfare system. The other group is families with children with disabilities who are somewhat arbitrarily put into the social welfare system, which is geared towards adults (Fünfter Jugendbericht der Bundesregierung, 1980, p. 97). These families are in a system that does not have an explicit perspective on the child, they get neither the financial resources nor the support and counselling that are available to parents in the child and youth welfare system, and they have developed into a kind of second-class foster family (Föltz, 2017 , p. 297). The last attempt, in 2018, to solve these discrepancies with reform at the legislative level failed.

However, many children and young people with special needs are living in foster families and profiting from a familial setting, but it could be even more. There are still too many being cared for in specialized group homes.

\section{Method}

Processes of education and individual educational formation are at the focus of educational science research. The research foundations of this study rely on qualitative approaches to biographical and educational research. Meanwhile, apart from sociology, biographical research has become a meaningful methodological component of educational science and its partial disciplines such as school pedagogy, adult education, and social pedagogy (Krüger, 2006, p. 22).

Some research questions can be explored more adequately with a qualitative approach than a quantitative one (Strauss \& Corbin, 1996, p. 3). Among these are questions that explore issues 
involving personal experiences, as did my research question, "How do foster parents deal with the challenges that are inherent to caring for children and youth with special needs?" The aim of this research question was to generate insights into how foster parents find ways on a personal and a practical level to deal with issues of disability and prejudice, and with the other difficulties they encounter in their daily lives. My study of 2017 took in the whole sphere of life of foster parents: biography, context of living, motivation to care for non-biological children, hopes, wishes, and specific burdens and problems.

A qualitative approach may be helpful to generate new insights in well-studied areas or to detect hidden details (Strauss \& Corbin, 1996, pp. 4-5); however, this approach is especially suitable for generating knowledge about an underexposed area and contributing to a better understanding of the issues involved. Because of the paucity of research done so far, this investigation was exploratory and its results are descriptive. It reconstructed the subjective patterns of explanations, theories of daily life, and perspectives of foster parents that lie behind the visible aspects of their coping strategies. These strategies were subjectively perceived as appropriate reactions to the challenge of providing care for a child or youth with high special needs. This reconstructive approach aimed to direct attention to the inner processes of foster parents and their families (Föltz, 2017, p. 98).

The empirical design involved the collection of data using the instrument of narrative inquiry through unstructured in-depth interviews and a standardized catalogue of open-ended questions after the narration was finished.

The sample criteria (Föltz, 2017, pp. 97-100) included foster parents who had decided to care for children and young people up to the age of eighteen with special needs. Children and young people were included who had a diagnosis, or special needs, that required them to attend specialized schools or kindergartens. In this study, I wanted to give space to the communication of individual experiences and not provoke valuations beforehand through artificial classifications of disabilities and impairments. The study used the unspecific terms "disabled or at risk of being disabled" of the SGB IX $\S 2$. The only criterion was that the needs of the child for assistance, care, and education exceeded the normal extent, as reflected by a diagnosis or attendance at specialized institutions. Therefore, no classification of the type of disability or impairment was applied, to avoid making a subjective judgement too quickly about the severity of a disability, which could result in individual valuations being lost: diagnoses might not correspond to what foster parents see as problematic, and another foster family may have a different view on the same diagnosis.

The sample comprises 19 interviews with foster parents from 15 families, 13 foster mothers and six foster fathers, with more than two thirds (14) reporting they had not known in advance about the special needs their child would have. Some of those foster parents even explicitly denied wanting to take in a child with special needs (4 out of 14). With six foster fathers in the sample, the proportion of interviewed foster fathers was almost a third. This is notable in the light of studies by Silver et al. (1998, as cited in Retzlaff, 2010) and Cohen (1999, as cited in Retzlaff, 2010). 
International Journal of Child, Youth and Family Studies (2020) 11(4): 132-151

Their research in the area of families with children with disabilities predominantly involved mothers, who were more likely than fathers to be in contact with medical and therapeutic institutions and were more easily available for investigations (Retzlaff, 2010, p. 60). Likewise, it was easier for the present study to motivate foster mothers than fathers. Most of the foster fathers were hesitant; they wanted to leave the interview to their partner because they found it difficult to “tell stories" (Föltz, 2017, pp. 97-98).

All collected data were included in the sample and transcribed. Because the data were specialized regionally to the state of Saxony-Anhalt in eastern central Germany, differences in the conditions of socialization between new states in the east and old states in the west of Germany were not examined. I found no hints in the literature that the ways in which foster families conduct their lives when caring for children with special needs would vary significantly by region within Germany. Also, there was no indication in the literature that the perspectives of foster parents were likely to differ by gender; therefore, gender-specific perspectives were not examined in this research.

Access to foster parents was found through the child and youth welfare system, the snowball principle (high willingness of interviewees to recommend other foster parents), and through workshops and speaking assignments.

The analysis of the material (Föltz, 2017, pp. 108-111) was guided by the analytic style of Strauss and Corbin's (1996) grounded theory in the process of dimensioning the interviews by open, axial, and selective coding, and by theoretical sampling. For the open coding step, the MAXQDA software was used. Through this approach, the interviews could be contrasted and compared, the case profiles depicted and clustered, and emerging patterns of strategies and their logic could be described. Grounded theory was used in combination with narrative analysis as described by Schütze (1983). The latter included the analysis of the transcribed data in five steps: (a) formal analysis of the text, which involves the technique of sequencing; (b) a structural description of the content; (c) the analytical abstraction; (d) the analysis of knowledge (theoretical statements of the interviewee); and (e) the contrastive comparison of the interviews, which draws on the deeper dimensions of the material to create a broader view of the data and allows the patterns therein to emerge.

\section{Structural Features}

Analysis of the material garnered the structural features (or codes) of building community, reflexivity, creating certainty, activating social and emotional resources, coping strategies, and perspectivity. These features served as dimensions for comparing all interviews in order to make the overall patterns visible and elucidate the differences between them.

- Building community means entering into close social and intimate bonds or commitments, as well as identifying with others around you. How is attachment, bonding, and the relationship with the child approached, arranged, and established? 
- Reflexivity is taken as a thoughtful, analytical reference to the self and the world for orientation, problem solving, self-assurance, or reasoning for decision-making.

- Creating certainty refers to the individual's way of gaining certainty in opinion and action. How much chaos and confusion can somebody stand, and how much does he or she need in order to stay flexible? Creative processing of experiences is possible only if one can tolerate a certain amount of uncertainty and vagueness in the process. Otherwise inflexible routines or rigidly regimented solutions develop.

- Activating social and emotional resources refers to efforts to access help and support in the personal context, the type and extent of the services sought, and what kind of assisting network is maintained.

- Coping strategies are ways of reacting to the phenomenon of disability and its challenges.

- Perspectivity stands for the repertoire of "frames" (Goffman 1986), the ability to perceive different frames in interactions (like a social or medical frame, or the frame of issues concerning disability and diversity), and the ability to change perspectives and walk in other people's shoes.

These features generated the discriminatory power to define patterns of specific strategies used by foster parents in reacting to the new and challenging situation they found themselves in. Through comparing the dimensions of the structural features, three patterns of strategies could be identified. See Table 1 for an overview of the scheme of features and the generated strategies.

Table 1. Features Used in Each of the Three Identified Patterns of Strategies

\begin{tabular}{llll}
\hline Feature & $\begin{array}{l}\text { Pattern A } \\
\text { Action-oriented }\end{array}$ & $\begin{array}{l}\text { Pattern B } \\
\text { Resource-oriented }\end{array}$ & $\begin{array}{l}\text { Pattern C } \\
\text { Reflection-oriented }\end{array}$ \\
\hline Building community & Affectual* $^{*}$ & Affectual/value-rational* & Value-rational* \\
Reflexivity & Limited & Medium & High \\
Creating certainty & High & Medium & Low \\
Resources & Limited use & High use & Directed use \\
Strategies of coping & Trial and error & Flexible if necessary & Flexible \\
Perspectivity & Basic frames & Differentiated frames & Multifaceted frames \\
\hline
\end{tabular}

*Terms from Weber, M. (1988). Gesammelte Aufsätze zur Wissenschaftslehre [Collected essays on science], pp. 565-567. J. B. C. Mohr (Paul Siebeck). (Original published 1922).

\section{Results}

In order to show the variety and richness of the sample, some aspects of the collected data concerning the sample will be pointed out in the hope that they may be of value to further research in the field (Föltz, 2017, pp. 262-264). Following this, I present three patterns (A, B, and C) of strategies for coping with the challenges of fostering children and youth with special needs. 
The average age of the 19 interviewees was 43.8 years. The youngest interviewee was 30 years old, the oldest 69 . Overall, the 15 foster families had taken 26 children and youth with disabilities and medical fragility into their care. The average number of biological children in a foster family was 2.3. Three families had no biological children; in four families the biological children had already moved out. In the remaining eight families, a total of 14 biological children were still living in the family home. One foster parent was single parenting; all other 14 families comprised both a female and a male caregiver.

Regarding the ages of the children at placement, 13 foster children out of $26(50 \%)$ were taken in from birth up to 2 years. Four children came into the family aged between 2 and 4 years (15\%) and nine children between 5 and 8 years (35\%). At the time of doing the interviews, there were six children aged between 8 months and 5 years, 10 children between 6 and 11 years, and 10 children and youth between 12 and 17 years.

The professions of the foster parents varied widely, as did their levels of school education. The reported professions were: shepherd, concrete worker, cook, nurse, pediatric nurse, physician's assistant, homemaker, occupational therapist, accountant, social worker, special education therapist, and retiree. Three of the 19 interviewees had a general qualification for university entrance (Abitur), 12 had a high school diploma (10. Klasse/Realschulabschluss), and four had completed a secondary school qualification (achte Klasse). It was evident that the strategies did not always correlate with the school level completed. For example, those foster parents with a qualification for university entrance were not necessarily found in the reflexivity-oriented pattern , although interviewees with less schooling tended to be found in the action-oriented pattern (Föltz, 2017, p. 263).

Disability and medical fragility range from developmental delays and learning disabilities, often following alcohol abuse during pregnancy or because of neglect, abuse, and domestic violence, to grave forms of disability and medical fragility that may even have fatal outcomes, and that necessitate intensive medical care. Some of the foster children in the study had mental disabilities because of absence of the corpus callosum, alcohol abuse (fetal alcohol syndrome disorder), trisomy 21 (Down syndrome), Fragile X syndrome, autism, distal 18q- (de Grouchy syndrome II), or brachycephaly (Föltz, 2017, pp. 263-264).

Results show that neither the specific form nor the severity of disability or medical fragility necessarily implies a specific level of stress. Interviewees reacted differently to comparable tensions, stresses, and challenges, and to the severity of their children's disabilities. Likewise, the form or severity of disability was not found to be associated with the pattern of strategies adopted. Rather, personal attitudes shaped the individual response to the challenging situation, as well as the personal meaning that was found in that special responsibility. Consistent with the fact that more than two thirds of the interviewees were surprised that their foster child had a disability, they reported firmly anchored prejudices and bewilderment. When foster parents meet a child in need, processes of change in attitude can be observed, depending on the foster parents' type of reflexivity 
and its level. In comparing the cases it became obvious that the different coping patterns were not directed or caused by outward stimuli. Likewise, the normative influence of society is not in direct correlation with attitudes towards the phenomenon of disability, nor with the mode of coping. Disability did not manifest itself as an objective, static factor, but as a relational, interactive process in which foster parents play an active role, bringing in their personal attitudes and experiences, an observation that Goffman stressed (Goffman, 1975, p. 12). Consistent with Goffman's findings, the study validated the relational aspect in the phenomenon of disability (Föltz, 2017, p. 264).

Regarding the question of the integration of a child into the foster family and the emotional bonding of the child and the foster parents, interviewees reported that the bonding process started during the initial meeting with staff from the child and youth welfare office. Getting to know the child's name and seeing a picture of the child generated the first subjective inner pictures, a feeling of belonging together, and identification with the history and fate of the child. The first visit with the child gave the foster parents a sense of the helplessness of the child. Evidence of neglect and the feeling that the child had often felt unwelcome were triggers for caring behavior and concern for the child. Subsequent visits to a hospital or another short-term foster family intensified the relationship. The family started longing to bring the child home and to create the relationship on their own. Some foster parents reported that they did not take notice of relevant information about a possible disability because they fell in love with the child. "Falling in love", "the right chemistry", or the fact that both sides immediately liked each other played an important role in the foster parents' feelings and the decision-making process. Other methods of integration can be traced through the acceptance of the foster child by the foster parents' own children, relatives, and friends. Foster parents also realized that their biological children often played a large part in the integration process and the development of the foster child (Föltz, 2017, pp. 268-269).

\section{Patterns}

Since the analysis of the material collected involved the analysis of patterns, the results will be outlined in three exemplary key patterns of strategies, each standing for a cluster of similar strategies used by the foster parents (see Table 1). The complementary variations of strategies by minimal and maximal contrast yielded the comprehensive spectrum of the sample (Föltz, 2017, pp. 109-110).

When labeling the different patterns that were used to cope with new and often unpredictable situations, it was evident that foster parents acted in an action-, resource-, or reflection-oriented way. On a motivational level, it was found that they were trying to create (or recreate) subjective normalcy (Föltz, 2017, pp. 260-261).

Having arrived at these three patterns of coping, an understanding of how foster parents manage, cope with, and master their family life is gained, which answers the research question sufficiently. Yet, on a deeper level this leads to the question of why foster parents individually choose a particular pattern. In looking at each individual way of coping, it became obvious that foster parents were aiming to create normalcy in various ways. They obviously attempted to create 
International Journal of Child, Youth and Family Studies (2020) 11(4): 132-151

(or recreate) normalcy in the encounter with the phenomenon of disability. This finding constituted normalcy as the key category. All dimensions of comparison - building community, reflexivity, creating certainty, activating social and emotional resources, coping strategies, and perspectivity - could be positioned around and integrated into the key category of normalcy. Although the relationship between disability and normalcy was not the focal point of the study, it is compatible with the current discussion (Föltz, 2017, pp. 270-281, 286).

For the given purpose, looking at how the different ways of coping interrelate with the key category of normalcy, it can be shown that each pattern responds to a specific kind of normalcy. It was found that a normative understanding of normalcy - that presuppositions are shaped solely by society, are not to be doubted, and have to be followed - underlies pattern A. With this strategy, foster parents are concerned about disability as falling short of the norm. Pattern B distinguishes itself by a so-called referential understanding of normalcy. When first encountering new phenomena like disability, these foster parents resort to a normative understanding of normalcy and normative valuations. But they are able to free themselves from societal presuppositions and turn to the new, as yet uncomprehended and unknown, reality of their children and explore it. Pattern $\mathrm{C}$ shows a divergent understanding of normalcy that not only can respect and appreciate otherness, but really welcomes it as a gain, enrichment, or asset, often in conscious opposition to societal expectations (Föltz, 2017, pp. 286-288).

\section{Pattern A}

Pattern A was labeled action-oriented (see Table 1). It can be described as building community "affectually" (term from Weber, 1922/1988, pp. 565-567) as it comes from a feeling of pointedly unconditional belonging even up to accepting being excluded together with the child (Föltz, 2017, p. 271). A high rate of activity is prominent, as are limited reflexivity, concerted attempts to create certainty and to avoid vagueness and chaos, a very limited use of resources, reliance on trial and error, and the use of basic frames for orientation, mostly familial and social. These kinds of views of the world have a binary quality, which reduces complexity, facilitating orientation to new and complex situations.

The protagonist foster mother is indeed constantly in action. She tries to tackle things immediately and as well as she can. She is constantly hovering above her foster son to prevent all kinds of situations that might cause damage to him, to others, or to things. The nine-year-old foster son has been living with them since he was 18 months old. He is very lively, constantly moving, can't sit still. He needs somebody at his side continuously to orient him in time and space and to keep him on track with assignments; and even while playing, so he can maintain his concentration and focus. He tends to have all kinds of accidents. He inflicts severe injuries on himself when he gets into a rage about what may seem like meaningless incidents, which frequently land the family in the emergency room of the nearest hospital. He needs a rigid regimen, rules, and structure. The foster mother is especially happy when things are working out and nothing serious happens during the day. In her opinion, the school, therapists, and official administration are not supportive enough 
and lack understanding of their situation. She complains that she does not receive nearly enough help and encouragement. In her opinion it is the fault of the professionals that her foster son is not able to reach his full potential - to grow into a normal young man who is able to live a normal life, as she calls it. She very much loves her foster son and strongly identifies with him. She defends him fervently against mean comments from people from outside and in all clashes with society (Föltz, 2017, pp. 146-182).

Prominent in this action-oriented pattern is that foster parents possess few resources, which therefore play only a minor part in their lives. The normative understanding of normalcy creates an attitude of demand. When met with difficulties such as refusal of support, withdrawal and frustration results. The most important background is the familial frame, yet this is limited since only part of the family can handle the situation with the foster child. Attempts to access resources do not succeed most of the time and take a lot of energy (Föltz, 2017, pp. 279-280).

The coping strategy of trial and error used in this pattern involves actions undertaken without a coherent plan. These may include: endeavors to gain preventive control of situations by, for example, talking to the store manager before visiting the store; avoidance of occasions such as visiting restaurants, stores, or medical facilities with the foster son; confrontation with political institutions like local municipal authorities; demands that workers like the speech therapist or the schoolteacher put efforts toward "making her foster son more normal"; and delegation of responsibilities like afternoon activities, homework, and hobbies to other institutions. Attempts to improve the situation by getting support or influencing institutions are undirected and unsuccessful (Föltz, 2017, p. 177).

These foster parents require administrative and supportive entities like child welfare systems and agencies to give extensive support, encouragement, and training to enable the family to get the needed assistance from third parties.

\section{Pattern B}

Then there is a group of foster parents who react in a different way to the challenges at hand. Pattern B is labeled resource-oriented (see Table 1). This pattern can be described as affectual/value-rational (term from Weber, 1922/1988, pp. 565-567) community building, which entails a differentiation between unconditional belonging, high identification, self-doubt, and mental and physical overload and strain, without losing the tight bond. These foster parents not only act on their inner feelings of love for their foster child, as in pattern A, but also describe and explain the inner process of bonding. They talk about "love at first sight" or say that they felt that the chemistry was right. They also state the need to love this child unconditionally in order to be able to withstand all coming challenges and strains. Characteristics of this pattern are medium levels of both reflexivity and creating certainty. Uncertainty for these foster parents is inherent in the process of their child's development (e.g., challenges with attachment, or developmental issues), or in their own learning processes (e.g., handling the medical system, or dealing with administrative agencies, schools, or kindergartens): they know that those processes take time and 
are not fully predictable. Most of all this pattern is notable for high use of resources and external help. Coping strategies can be chosen flexibly if circumstances require it. A parent in pattern B is able to perceive differentiated frames, whether personal, social, medical, professional, societal, or institutional. Compared to pattern A, many more, and more complex, frames or perspectives on life are found; their outlook is not merely binary but takes in the grey areas as well. However, this makes orientation in complex situations harder. Unlike in pattern A, social competencies are highly developed; for example, attempts to improve the situation and get the help needed are addressed to the right person or agency and thus are mostly successful (Föltz, 2017, p. 272).

Prominent in the pattern of features that make up pattern B is a large network of different resources to draw on for support, one that foster parents have searched, developed, shaped, and fostered. In their referential understanding of normalcy, resources constitute a bridge between the normal world and the previously unknown one of disability, in which they often reach the limits of their means and require help (Föltz, 2017, pp. 280-281).

In this pattern, coping strategies are geared towards working actively on behalf of the child by engaging on a number of administrative levels like school, kindergarten, medical support systems, the communal help system, or the local child and youth welfare bureau. Some are even politically active, talking to community leaders or writing petitions. In this pattern, foster parents control the effectivity of their actions and avoid putting energy into ineffective actions: they are aware of what is going on in the inner and outer circles of their life space. These foster parents are also aware of the choices they have and share a broad perspective, creating, using, and fostering their resources constructively. They try to see both sides in a conflict and to be realistic and objective. Hence, their attempts to exert influence on institutions to improve their situation are often successful (Föltz, 2017, pp. 280-281).

The protagonist family of this pattern cares for a foster son who came into the family directly from the hospital with a severe brain growth and a fatal prognosis when he was a couple of weeks old. Day and night there have been emergency episodes of near-suffocation, intense medical care, and frequent stays at the hospital together with the foster mother. All of the family is working together in trying to get him through all the critical situations and help him survive and have a life. The foster mother has a good friend who is a pediatrician; the family also has a physiotherapist and speech therapy in place. They found a kindergarten that is ready to take and integrate him. They also have an au pair living with them and other household help. The foster mother worries about the possibility of her biological children being harmed through this stressful family life, and not being able to have enough time for them. The foster parents try to compensate for the lack of time, and for not being able to go on vacations with the children, through special events and extras like having a pool or a sauna at home to make a nice spot in the garden where they can invite friends and have a good time. The family also have good relations with the local child and youth welfare office (Föltz, 2017, pp. 183-219). 
International Journal of Child, Youth and Family Studies (2020) 11(4): 132-151

Foster parents using this resource-oriented pattern of strategies need fewer practical interventions from administrative and supportive systems but more conversations and discussions to consider and weigh the options. They need recognition and appreciation of their engagement and endeavors to support the child or youth in their care.

\section{Pattern $C$}

Pattern C, which is reflection-oriented (see Table 1), is characterized by value-rational (term from Weber, 1922/1988, pp. 565-567) community building, which denotes strong identification with the foster children as well as heightened mindfulness of their personality, needs, and rights. A high level of reflexivity, a low level of needing to create certainty, a directed or focused use of resources and external help, and flexible coping strategies make for a high level of effectivity and flexibility in acting and reacting. Where pattern B was typified by personal, social, medical, professional, societal, and institutional perspectives, pattern $\mathrm{C}$ shows multifaceted options to identify and handle the even more complex structural, ethical, and philosophical frames of reality (Föltz, 2017, pp. 273-274, 281). The reflexivity in this pattern is especially prominent in its perspective on the structure of services, relationships, and administrative bodies, in its ethical view of life, and in its engagement with philosophical and political issues relating to fostercare and the experience of being a foster parent of a child with a disability. Although additional complexity makes for more uncertainty and less orientation in new situations, such challenges can be tolerated and endured in this pattern.

Although there are resources available, these parents use them frugally. Because of their divergent, more tolerant, understanding of normalcy, the search for help does not seem so urgent. When foster parents in pattern $\mathrm{C}$ reach their limits, resources are used purposefully, effectively, and successfully. Resources are simply available and play a less significant role than in pattern B, where resources are constantly searched for and maintained (Föltz, 2017, p. 280).

Coping strategies in this pattern are first of all a reflexive procedure that leads to overcoming resistance and finding creative solutions. Strategies include changing perspectives for gaining understanding, and maintaining a consciously positive attitude, flexibility, and an awareness of accompanying and fostering a child or youth (Föltz, 2017, p. 281).

The reflection-oriented pattern $\mathrm{C}$ is characterized by a single-parenting foster father of an 8year-old boy he got to know through his work as a physiotherapist at a local residential group home. Their bond grew tighter and tighter over time. He actually thought about fostering because his job at the residential home came to an end and he needed to leave for another job. The boy started to refuse to eat and developed behavioral problems. The child welfare office was helpful and flexible in accepting him as a foster father. Over time, he discovered that his foster son, in addition to his mental disability, was severely traumatized through his childhood experiences, and that it would take all his strength and creativity to give his son the support he needed. When difficult situations were pending, he sought information and professional help to sort through his preferences and possibilities before he acted. As a result, when acting upon a problem, he was 
International Journal of Child, Youth and Family Studies (2020) 11(4): 132-151

successful most of the time. His relationship with his foster son was most important to him, and he tried always to take his son's perspective into account and to learn to see the world through his son's eyes (Föltz, 2017, pp. 220-259).

Foster parents who use pattern $\mathrm{C}$ are less in need of practical help or broad discussions about options but require more recognition of their efforts and a few hints and tips when needed. Mostly these families are left alone because they seem to do so well on their own. Nevertheless they need some professional attention once in while.

\section{Conclusion}

Foster care for children and youth with disabilities in Germany is a small part of the child and youth welfare system and, as yet, little research has been done on it. The qualitative study presented here generated insights into how a child is integrated into the foster family and how foster parents bond emotionally with their children. It also showed how the mobilization of resources and the development of strategies for handling the challenging situation are evolving.

Notably, the study generated three patterns of strategies that foster parents use to deal with the challenging situation of having a high special needs child or youth as a result of disability and medical fragility along with traumatic experiences. Foster mothers and fathers react in applying an action-, resource-, or reflection-oriented strategy based on their personal biographic experiences and their worldview. Understanding these three ways of coping that foster parents use to master the challenging situation will give counsellors and social workers in the administrative agencies and systems a unique and tailored approach to recruit, retain, and train foster families adequately. Recruiting new and qualified foster families is a challenge in every European country (Küfner \& Schönecker, 2011, pp. 93-99).

Some families ( Pattern A: Action) need more assistance; these families can get very frustrated if this support is not given. Lacking support, they may give up or not be willing to foster again. Other families (Pattern B: Resources) need less hands-on help than the families who use an actionoriented strategy. They want to be directed towards the possibilities and resources they need to function well. And still other families ( Pattern C: Reflection) just want a little encouragement or some suggestions, but otherwise need their space to do it their way. These families appreciate a reflective conversation to discuss a problem and suggest possibilities, but prefer to have the course of events and decisions left to them. They get irritated if too much support is forced upon them and they may also not be willing to take on another placement of a child.

By keeping these three patterns in mind, finding the right style of support for every family becomes less of a puzzling individual search for the right thing for a specific family. Considering which pattern a family uses could be an effective way to quickly estimate the style of communication and assistance needed in order to recruit, retain, and train foster families. 
These coping patterns are not to be understood as static but rather biographically dynamic. They are merely a snapshot in time in the life of the interviewed foster parents. Ongoing experiences and clashes of frames, external stimulation, and support can change and further shape the relation to the self and the worldview of the individual. At this point, society can have a great influence on this educational formation process of foster parents and their ability to deal with processes of stigmatization and marginalization by providing the competencies and resources of its institutions. Being supported in these ways, foster parents can have a reciprocal effect on society with their specific abilities gained through fostering in a challenging situation, thus generating an active and public climate of inclusion. 
International Journal of Child, Youth and Family Studies (2020) 11(4): 132-151

\section{References}

Braches-Chyrek, R., Macke, K., \& Wölfel, I. (2010). Kindheit in Pflegefamilien [Childhood in foster care]. Verlag Barbara Budrich.

Engelbert, A. (1999). Familien im Hilfenetz. Bedingungen und Folgen der Nutzung von Hilfen für behinderte Kinder [Families in the help network: Conditions and consequences of using aids for disabled children]. Juventa.

Föltz, F. (2017). Herstellung von Normalität - Mikrostudien zur Situation von Pflegemüttern und -vätern im Umgang mit besonderen Bedürfnissen von Kindern und Jugendlichen mit Behinderung [Creating normalcy: Microstudies on the situation of foster mothers and fathers in dealing with the special needs of children and youth with disabilities; Unpublished doctoral dissertation]. Otto-von-Guericke-Universität Magdeburg.

Fünfter Jugendbericht der Bundesregierung [Fifth youth report by the federal government]. (1980). Bericht über Bestrebungen und Leistungen der Jugendhilfe. D 3 Pflegekinderwesen und Adoption [Report on efforts and achievements of youth welfare. D 3 Foster childcare and adoption]. https://www.dji.de/fileadmin/user_upload/bibs/5 Jugendbericht.pdf

Gadow, T., Peucker, C., Pluto, L., van Santen, E., \& Seckinger, M. (2013). Wie geht's der Kinder- und Jugendhilfe [How is the child and youth welfare department doing]? Beltz Juventa.

Goffman, E. (1975). Stigma. Über Techniken der Bewältigung beschädigter Identität [Stigma. Notes on the Management of Spoiled Identity]. Suhrkamp.

Goffman, Erving (1986). Frame analysis: An essay on the organization of experience. New York, Pennsylvania: (The Maple Press). (Original published 1974). https://is.muni.cz/el/1423/podzim2013/SOC571E/um/E.Goffman-FrameAnalysis.pdf

Hanselmann, P. G., \& Weber, B. (1986). Kinder in fremder Erziehung. Heime, Pflegefamilien, Alternativen - ein Kompass für die Praxis [Children raised by others. Homes, foster families, alternatives - a compass for practice]. Beltz.

Heinen, N., \& Höning, K. (1999). Pflegeeltern von Kindern mit geistiger Behinderung [Foster parents of children with intellectual disabilities]. Geistige Behinderung, 38(3), 274-290.

Kindler, H., Helming, E., Meysen, T., \& Jurczyk, K. (Eds.). (2011). Handbuch Pflegekinderhilfe [Handbook of foster care]. Deutsches Jugendinstitut.

Koppe, S., Malter, C., \& Stallmann, M. (2000). Zur Situation von Familien mit behinderten Pflegekindern [On the situation of families with disabled foster children]. Forum Jugendhilfe, $1,42-52$. 
International Journal of Child, Youth and Family Studies (2020) 11(4): 132-151

Krüger, H.-H. (2006). Entwicklungslinien, Forschungsfelder und Perspektiven der erziehungswissenschaftlichen Biographieforschung [Lines of development, research fields and perspectives of educational biography research]. In H.-H. Krüger \& W. Marotzki (Eds.), Handbuch erziehungswissenschaftliche Biographieforschung [Handbook of educational biographical research] (pp. 13-33). VS Verlag für Sozialwissenschaften. doi:10.1007/978-3531-90010-0_2

Küfner, M., \& Schönecker, L. (2011). Rechtliche Grundlagen und Formen der Vollzeitpflege [Legal bases and forms of full-time care]. In H. Kindler, E. Helming, T. Meysen, \& K. Jurczyk (Eds.), Handbuch Pflegekinderhilfe [Handbook of foster care] (pp. 93-99). Deutsches Jugendinstitut.

Kwapil, H. (1987). Erfahrungen mit einer sozialpädagogischen Institution - Ergebnisse einer Studie über Selbstinterpretation und Selbstdarstellung heilpädagogischer Pflegepersonen [Experiences with a socio-pedagogical institution: Results of a study on self-interpretation and self-portrayal of curative educational carers]. Universität Tübingen.

Landesverwaltungsamt Sachsen-Anhalt [State Administrative Office of Saxony-Anhalt]. (2003). Statistik 2003. Landesjugendamt [State Youth Welfare Office].

Landesverwaltungsamt Sachsen-Anhalt [State Administrative Office of Saxony-Anhalt]. (2014). Statistik 2014. Landesjugendamt [State Youth Welfare Office].

Masur, R., Tiesler, J. A., \& Schiel, W. (1982). Eingliederung behinderter Kinder in Pflegefamilien. Das soziale, klinisch-psychologische Konzept [Integration of disabled children into foster families: The social, clinical-psychological concept]. Ernst Reinhardt.

Retzlaff, R. (2010). Familien-Stärken. Behinderung, Resilienz und systemische Therapie [Family strengths: Disability, resilience, and systemic therapy]. Klett-Cotta.

Roos, G. (1996). Behinderte Pflegekinder [Disabled foster children]. In U. Gintzel (Ed.), Erziehung in Pflegefamilien. Auf der Suche nach einer Zukunft [Upbringing in foster families: Looking for a future] (pp. 197-200). Votum.

Sarimski, K. (2014). Familiäre Belastungen in Pflege- und Adoptivfamilien mit Kindern mit fetalem Alkoholsyndrom [Familial stresses and strains in foster and adoptive families with children with fetal alcohol syndrome]. Praxis der Kinderpsychologie und Kinderpsychiatrie, 63(8), 649-666. doi:10.13109/prkk.2014.63.8.649

Schäfer, D. (2011). Ressource Pflegeeltern. Untersuchung der Belastungen und Ressourcen von Menschen, die Pflegekinder mit chronischen Erkrankungen und Behinderungen betreuen [Resource foster parents: Investigation of the pressures and resources of people caring for foster children with chronic illnesses and disabilities]. Universität Siegen. 
International Journal of Child, Youth and Family Studies (2020) 11(4): 132-151

Schönecker, L. (2011). Pflegekinder mit Behinderung [Foster children with disability]. In H. Kindler, E. Helming, T. Meysen, \& K. Jurczyk (Eds.), Handbuch Pflegekinderhilfe [Handbook of foster care] (pp. 806-813). Deutsches Jugendinstitut.

Schütze, F. (1983): Biographieforschung und narratives Interview [Biographical research and narrative interview]. Neue Praxis. Kritische Zeitschrift für Sozialarbeit und Sozialpädagogik, 13(3), 283-293. https://nbn-resolving.org/urn:nbn:de:0168-ssoar-53147

Sozialgesetzbuch VIII. (2020). https://www.sozialgesetzbuch-sgb.de/sgbviii/1.html

Sozialgesetzbuch IX (2019). https://www.sozialgesetzbuch-sgb.de/sgbix/80.html

Statistisches Bundesamt Wiesbaden [Federal Office of Statistics Wiesbaden]. (2009). Statistiken der Kinder- und Jugendhilfe Erzieherische Hilfe, Eingliederungshilfe für seelisch behinderte junge Menschen, Hilfe für junge Volljährige. Heimerziehung, sonstige betreute Wohnform [Revidierte Ergebnisse; Statistics of child and youth welfare: Educational help, integration help for emotionally disabled young people, help for young adults. Residential care, other forms of residential care (Revised results)].

https://www.destatis.de/GPStatistik/servlets/MCRFileNodeServlet/DEHeft_derivate_0001493 9/5225113077004.pdf

Statistisches Bundesamt Wiesbaden [Federal Office of Statistics Wiesbaden]. (2013). Statistiken der Kinder- und Jugendhilfe. Erzieherische Hilfe, Eingliederungshilfe für seelisch behinderte junge Menschen, Hilfe für junge Volljährige [Statistics of child and youth welfare:

Educational help, integration help for emotionally disabled young people, help for young adults].

https://www.destatis.de/GPStatistik/servlets/MCRFileNodeServlet/DEHeft_derivate_0001493 0/5225112137004.pdf

Statistisches Bundesamt [Federal Office of Statistics]. (2018). Statistiken der Kinder- und Jugendhilfe. Erzieherische Hilfe, Eingliederungshilfe für seelisch behinderte junge Menschen, Hilfe für junge Volljährige [Statistics of child and youth welfare: Educational help, integration help for emotionally disabled young people, help for young adults]. https://www.destatis.de/DE/Themen/Gesellschaft-Umwelt/Soziales/KinderhilfeJugendhilfe/Publikationen/Downloads-Kinder-und-Jugendhilfe/erzieherische-hilfe$\underline{\text { 5225112187005.xlsx?_blob=publicationFile }}$

Strauss, A., \& Corbin, J. (1996). Grundlagen qualitativer Sozialforschung [Grounded Theory pocedures ans techniques]. Beltz.

Thiersch, H. (1992). Lebensweltorientierte Soziale Arbeit. Aufgaben der Praxis im sozialen Wandel [Environment-oriented social work: Practical tasks in the face of social change]. Juventa. 
International Journal of Child, Youth and Family Studies (2020) 11(4): 132-151

Trede, W. (2001). Stationäre Erziehungshilfen im europäischen Vergleich [Residential educational aids in a European comparison]. In V. Birtsch, K. Münstermann, \& W. Trede (Eds.), Handbuch Erziehungshilfen. Leitfaden für Ausbildung, Praxis und Forschung [Handbook of educational aids: Guide to training, practice and research] (pp. 197-212). Votum.

Trede, W. (2002). Was sind erzieherische Hilfen [What are educational aids]? In H.-U. Krause \& F. Peters (Eds.), Grundwissen erzieherische Hilfen. Ausgangsfragen, Schlüsselthemen, Herausforderungen [Basic knowledge of educational aids: Initial questions, key issues, challenges] (pp. 11-28). Votum.

Weber, M. (1988). Gesammelte Aufsätze zur Wissenschaftslehre [Collected essays on science]. J. B. C. Mohr (Paul Siebeck). (Original published 1922.) 